\title{
Taxonomic studies on wood inhabiting polypores from Chennai
}

\author{
Kezhocuyi Kezo, G. Sugantha and K. Malarvizhi* \\ CAS in Botany, University of Madras, Guindy Campus, Chennai-600025, Tamil Nadu. \\ *Corresponding author Email: malar.kaliyaperumal@gmail.com
}

(Submitted on October 28, 2019; Accepted on December 23, 2019)

\begin{abstract}
A total of eleven polypore species, Coriolopsis aspera (Jungh.) Teng, C. Caperata (Berk.) Murrill, C. Polyzona (Pers.) Ryvarden, Daedalea quercina (L.) Pers., Earliella scabrosa (Pers.) Gilb. \& Ryvarden, Flavodon flavus (Klotzsch) Ryvarden, Hexagonia hirta (P. Beauv.) Fr., H. tenuis (Hook.) Fr., Laetiporus sulphureus (Bull.) Murrill, Polyporus varius (Pers.) Fr. and Truncospora tephropora (Mont.) Zmitr. belonging to three families under order Polyporales are described and illustrated for the first time from Chennai (Tamil Nadu).
\end{abstract}

KEYWORDS: Basidiomycota, polypores, wood-decay, taxonomy. \section{INTRODUCTION}

Polypores are one of the most dynamic and diverse group of fungi, which are well known for their wood decaying property that ultimately, contributes towards the maintenance of forest ecosystem by recycling the minerals (Christensen et al., 2005). Majority of the polypores have been grouped under order Polyporales which are characterized by resupinate, effused, effused-reflexed, to pileate basidiocarps that can be stipitate or sessile (Binder et al., 2005). The hymenial surface may be poroid, lamellate, daedaloid or hydnoid. Anatomically, the hyphal system may be monomitic, dimitic or trimitic (Gilbertson and Ryvarden, 1986). Gäumann (1926) proposed the order Polyporales with ten families, based on their morphological characters. Later, with the development of molecular techniques, Binder et al. (2013) and Justo et al. (2017) recognized 41 families under the order Polyporales. At present, MycoBank (http://www.mycobank.org) record showes 77 families with over 1800 described species making it one of the largest order in Agaricomycotina (Kirk et al., 2008).

Chennai, located at the eastern coast of India and northeastern to southeastern Tamil Nadu has an average elevation of $6.7 \mathrm{~m}$ and covers an area of about $1189 \mathrm{~km}^{2}$. The climate of Chennai is typically hot and humid with three distinct meteorological seasons of summer (Feb-May), monsoon (Jun-Sep) and winter (Oct-Jan). However, taxonomy of macrofungi is poorly documented in Chennai. Initially, Sundaramani and Madurajanin (1925) studied the polypores of Tamil Nadu followed by contributions of Natarajan and Kolandavelu (1998), Selvam et al., (2012), Malarvizhi (2014) and Priyamvada et al ., (2017). The present paper is in continuation to the earlier publication by Kezo et al., (2019). This is a preliminary attempt to document the diversity of polypores in Chennai. Twenty one specimens belonging to 11 species of polypore fungi collected from different locations of Chennai during 2015 to 2018 have been illustrated and described with phenetic and micro-taxonomic characters for the first time from the study area.

\section{MATERIALS AND METHODS}

Collection and macro-microscopical characterization: Several field trips were carried out to collect polypores in three areas of Chennai, namely Guindy, Adyar and Tambaram during monsoon season. Locality and host of the basidiomata were recorded and photographed in their natural habitats.
Morphological characters of the basidiomata such as shape, size, color, etc. were recorded. The colour reference is as per Kornerup and Wanscher (1981). The fresh basidiomata were dried at $45-55^{\circ} \mathrm{C}$ in an electric drier for 24 hours and were preserved in sealed polythene bags with naphthalene balls. Thin sections were cut from basidiomata and studied using CLX2 Labomed microscope. Sections were mounted in cotton blue $(\mathrm{CB})$, Melzer's reagent and $5 \%$ potassium hydroxide $(\mathrm{KOH})$. Microscopic descriptions are based on the hyphal construction, pigmentation, presence/absence of cystidia, shape and size of basidia and basidiospores, etc. (Sharma, 2012; Núñez and Ryvarden, 2001).

\section{RESULTS AND DISCUSSION}

In all 11 species belonging to 8 genera and 3 families, namely Fomitopsidaceae (Daedalea quercina, L. sulphureus), Meruliaceae (Flavodon flavus) and Polyporaceae (Coriolopsis aspera, C. caperata, C. polyzona, Earliella scabrosa, Hexagonia hirta, H. tenuis, Truncospora tephropora, and Polyporus varius) of the order Polyporales are illustrated and described on the basis of specimens collected from different localities of Chennai, Tamil Nadu.

\section{TAXONOMIC DESCRIPTIONS}

1. Coriolopsis aspera (Jungh.) Teng, Zhong Guo De Zhen Jun [Fungi of China]: 759 (1963).

Fig.1

Basidiocarp annual, effused-reflexed to pileate, sessile, solitary, dimidiate; corky when fresh, leathery on drying; pileus up to $80 \times 40 \times 9 \mathrm{~mm}$; abhymenial surface velutinate to hirsute, rarely glabrous, concentrically zonate with alternating zones of dark brown (6F5) to light brown (6D5) and dark brown (8F3), not changing on drying; hymenial surface poroid, brown (6E7), not changing on drying; pores round, 3-4 per mm; Context homogenous, zonate, light brown (6D5), up to $5 \mathrm{~mm}$ in thickness, tissue turning dark brown in $\mathrm{KOH}$; pore tubes brown (6E7), up to $4 \mathrm{~mm}$ in thickness; margins acute, rusty brown (6E8), up to $2 \mathrm{~mm}$ in thickness. Hyphal system trimitic. Generative hyphae thinwalled, hyaline, clamped, branched, up to $4 \mu \mathrm{m}$ wide. Skeletal hypahe thick-walled, aseptate, up to $5 \mu \mathrm{m}$ wide, rarely encrusted. Binding hyphae thick-walled, aseptate, up to $3 \mu \mathrm{m}$ wide, highly branched. Basidia clavate, 4 sterigmate, 14-22 $\times 3-5 \mu \mathrm{m}$. Basidiospores cylindrical, (8.2-) 8.5-10.8 (11.4) $\times(3-)$ 3.2-4 (-4.5) $\mu \mathrm{m}, \mathrm{Q}=2.4$, thin-walled, hyaline, $\mathrm{CN}^{-}, \mathrm{IK}^{-}$. 


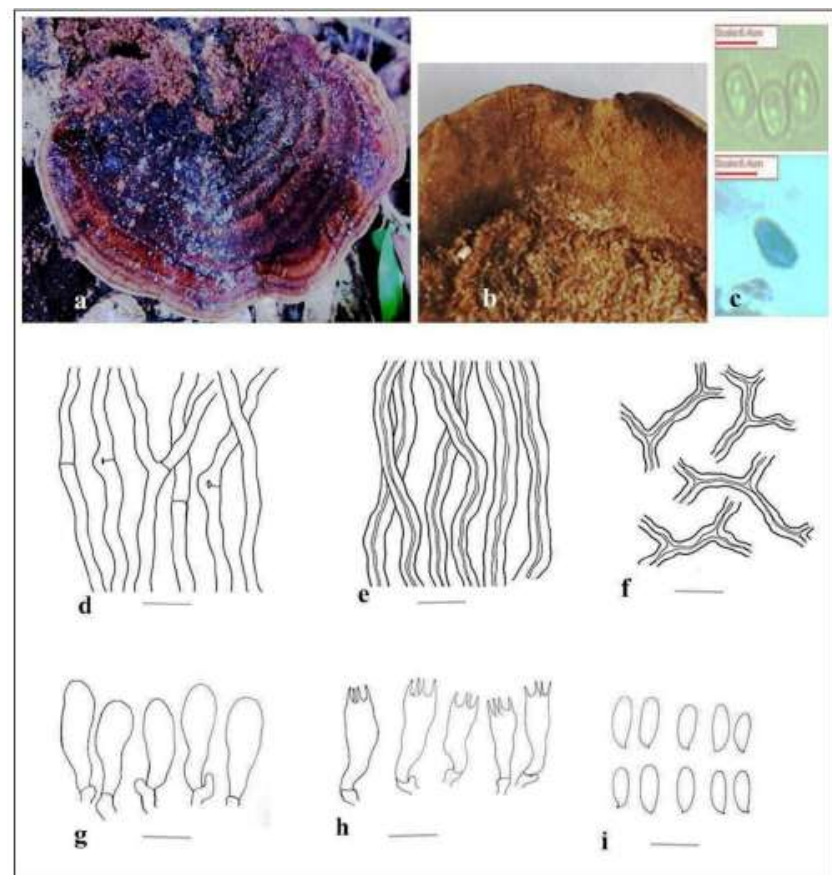

Fig.1. Coriolopsis aspera: a. Sporocarp (abhymenial surface), b. Hymenial surface, c. Basidiospores in water and cotton blue, d. Generative hyphae, e. Skeletal hyphae, f. Binding hyphae, g. Basidioles, h. Basidia, i. Basidiospores. Scale bar $\mathrm{d}-\mathrm{i}=10 \mu \mathrm{m}$

Specimen examined: India, Tamil Nadu, Chennai, Guindy, in association with dead wood, $\left(13^{\circ} 00^{\prime} 03^{\prime \prime} \mathrm{N}, 80^{\circ} 14^{\prime} 26^{\prime \prime} \mathrm{E}\right)$, MLCASB023, 31.10.2015, G. Sugantha.

Comments: The macroscopic and microscopic characters of the present specimen are consistent with the earlier report (Sharma, 2012) except for the colour of the context and the size of basidiospores. In India, it has been reported from Assam (Bose, 1937; Bakshi, 1971), West Bengal (Banerjee, 1947; Bakshi, 1971; Sharma, 2000 and 2012), Andaman Islands (Bakshi, 1971), Gujarat (Arya et al., 2008) and Andhra Pradesh (Nagadesi et al., 2014).

\section{Coriolopsis caperata (Berk.) Murrill, North American} Flora 9(2): 77 (1908).

Fig.2

Basidiocarp annual, pileate, sessile, flexible when fresh, hard and woody on drying; pileus up to $70 \times 45 \times 5 \mathrm{~mm}$; abhymenial surface narrowly zonate with alternating colours of yellowish brown (5E5) and dark brown (7F7), tomentose, not changing on drying; hymenial surface poroid, yellowish dark blond (5D4) when fresh, turning yellowish brown (5E5) on drying; pores round to angular to irregular, 3-5 per mm; context duplex in young basidiocarps, becomes more or less homogenous on maturity, up to $3 \mathrm{~mm}$, yellowish brown (5E5), tissue turning dark brown in $\mathrm{KOH}$; pore tubes inseparable, yellowish dark blond (5D4), up to $1 \mathrm{~mm}$ in depth; margins acute, greyish brown (8F3), up to $2 \mathrm{~mm}$ in thickness. Hyphal system trimitic. Generative hyphae thin-walled, hyaline, branched, clamped, up to $3.5 \mu \mathrm{m}$ wide. Skeletal hyphae thick-walled, unbranched, aseptate, up to $6.8 \mu \mathrm{m}$ wide. Binding hyphae thick-walled, irregularly branched, aseptate, up to $3.8 \mu \mathrm{m}$ wide. Basidia clavate, usually 4

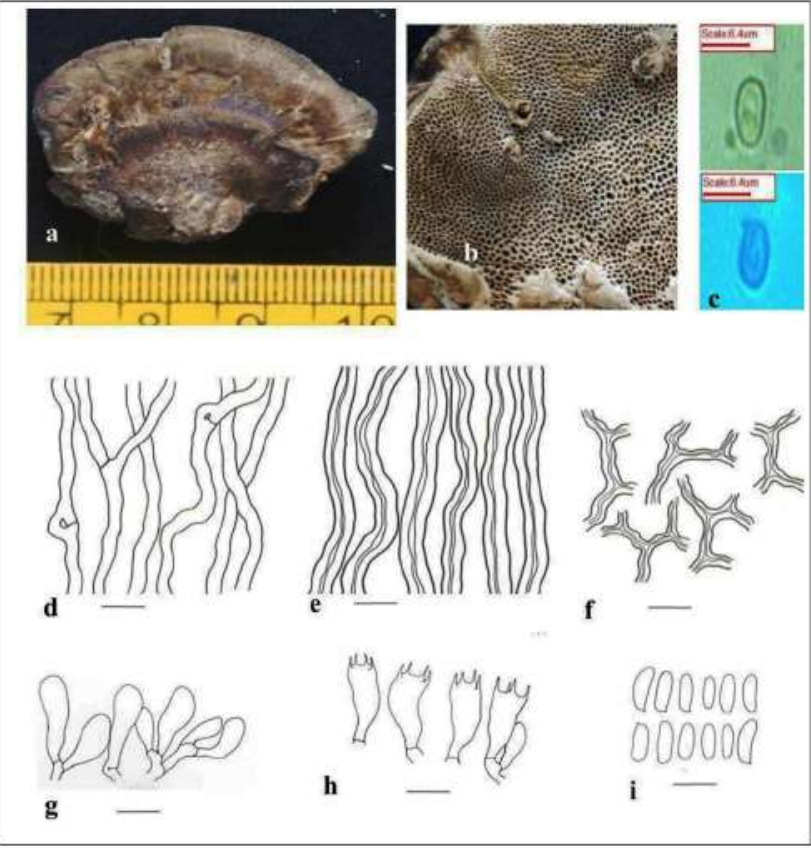

Fig.2. Coriolopsis caperata: a. Sporocarp (abhymenial surface), b. Hymenial surface, c. Basidiospores in water and cotton blue, d. Generative hyphae, e. Skeletal hyphae, f. Binding hyphae, g. Basidioles, h. Basidia, i. Basidiospores. Scale bar $\mathrm{d}-\mathrm{i}=10 \mu \mathrm{m}$

sterigmate, $13-21 \times 3.8-5.5 \mu \mathrm{m}$. Basidiospores cylindrical, (7-) $7.5-9.5(-10.5) \times(2-) 2.5-3.2(-3.5) \mu \mathrm{m}, \mathrm{Q}=2.5$, hyaline, thin-walled $\mathrm{CN}^{-}$, IKI.

Specimen examined: India, Tamil Nadu, Chennai, Guindy, in association with dead wood $\left(13^{\circ} 00^{\prime} 34^{\prime \prime} \mathrm{N}, 80^{\circ} 14^{\prime} 14^{\prime \prime} \mathrm{E}\right)$, MLCASB264, 09.11.2015, G. Sugantha.

Comments: Coriolopsis caperata is unique in having pielate basidiocarps with tomentose abhymenial surface and duplex context. From India it has been reported from Assam (Bose, 1937; Bakshi, 1971), Andaman Islands (Bakshi, 1971), Madhya Pradesh (Bakshi, 1971), Tamil Nadu (Bakshi, 1971), West Bengal (Bakshi, 1971; Sharma and Ghosh, 1989), Kerala (Leelavathy and Ganesh, 2000), Arunachal Pradesh (Sharma, 2012), Himachal Pradesh (Kaur, 2013), Uttarakhand (Sharma, 2012) and Punjab (Kaur, 2017).

3. Coriolopsis polyzona (Pers.) Ryvarden, Norwegian Journal of Botany 19: 230 (1972).

Fig.3

Basidiocarp annual, pileate, sessile, dimidiate, broadly and firmly attached, corky when fresh, leathery on drying; pileus up to $120 \times 50 \times 20 \mathrm{~mm}$; abhymenial surface concentrically zonate, pale yellow (3A3) when fresh, becoming yellowish brown (6E7) on drying; hymenial surface poroid, pale yellow (3A3), not changing on drying; pores round to angular, 2-3 per $\mathrm{mm}$; context duplex, lower part fibrous, upper part compact, pale yellow to yellow (3A3), up to $10 \mathrm{~mm}$ in thickness; pore tubes light yellow (4A3), up to $3 \mathrm{~mm}$ in depth; margins acute, light yellow (4A3), up to $2 \mathrm{~mm}$ in thickness. Hyphal system trimitic. Generative hyphae thin-walled, branched, clamped, up to $3 \mu \mathrm{m}$ in width. Skeletal hyphae dominating in context, thick-walled, light yellowish, aseptate, up to $6 \mu \mathrm{m}$ in width. 


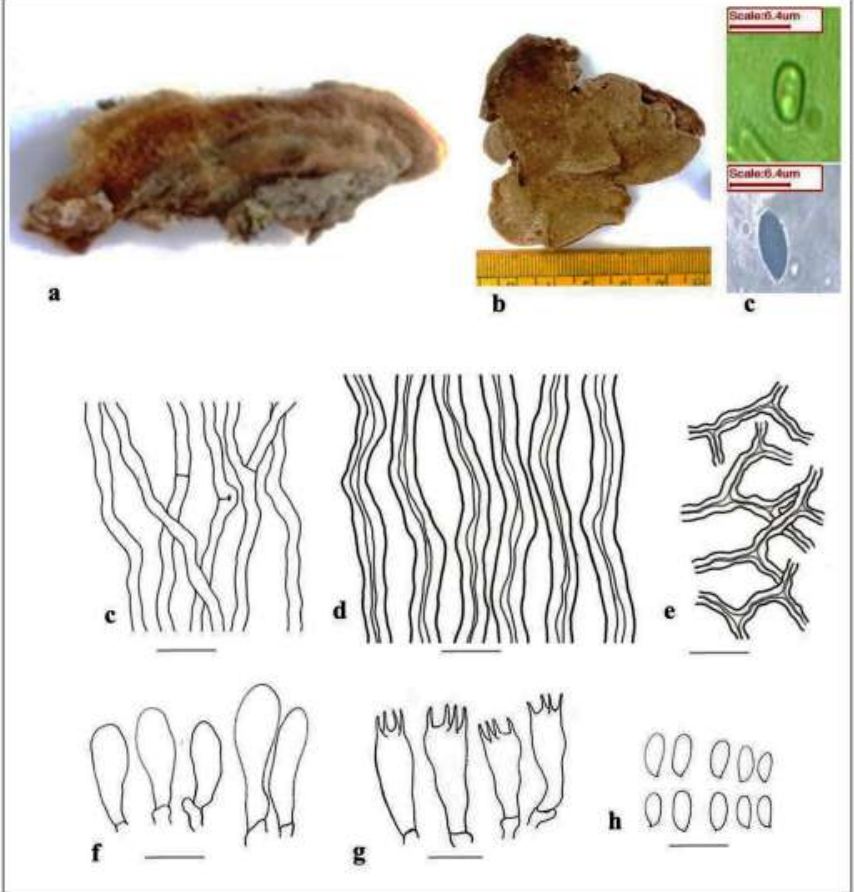

Fig.3. Coriolopsis polyzona: a. Sporocarp (abhymenial surface), b. Hymenial surface, c. Basidiospores in water and cotton blue, d. Generative hyphae, e. Skeletal hyphae, f. Binding hyphae, g. Basidioles, h. Basidia, i. Basidiospores. Scale bar $\mathrm{d}-\mathrm{i}=10 \mu \mathrm{m}$.

Binding hyphae thick-walled, hyaline, aseptate, irregularly branched, up to $3 \mu \mathrm{m}$ in width. Basidia clavate, 4 sterigmate, $17-26 \times 5-7 \mu \mathrm{m}$. Basidiospores oblong elongate, (5-) 5.2-7.5 $(-8) \times(2.5-)$ 3-3.4 (-3.8) $\mu \mathrm{m}, \mathrm{Q}=1.7$, thin-walled, hyaline, $\mathrm{CN}^{-}, \mathrm{IK}^{-}$.

Specimen examined: India, Tamil Nadu, Chennai, Tambaram, in association with dead wood, $\left(12^{\circ} 55^{\prime} 11^{\prime \prime} \mathrm{N}\right.$ $80^{\circ} 07^{\prime} 13^{\prime \prime E}$ ), MLCASB360, 13.10.2015, Tenzing Sangmo; Guindy, in association with dead wood, $\left(13^{\circ} 00^{\prime} 36^{\prime \prime} \mathrm{N}\right.$ $\left.80^{\circ} 14^{\prime} 17^{\prime \prime E}\right)$, MLCASB017, 31.10.2015, Sugantha G.

Comments: Coriolopsis polyzona is characterized by dimidiate basidiocarps, duplex context and oblong-elongate basidiospores. Earlier reports of this fungus from India include; West Bengal (Banerjee, 1947; Bakshi 1971), Kerala (Leelavathy and Ganesh, 2000), Andhra Pradesh and Himachal Pradesh (Sharma, 2012).

4. Daedalea quercina (L.) Pers., Synopsis methodica fungorum: 500 (1801).

Fig. 4

Basidiocarp perennial, pileate, sessile, solitary, firmly attached, semi-circular, flat to slightly convex, corky when fresh, hard on drying; pileus up to $150 \times 80 \times 25 \mathrm{~mm}$, thickening towards the attachment; abhymenial surface broadly zonate, orange white (5A2) when fresh, greyish yellow (6B3) on drying, glabrous to somewhat velutinate, hymenial surface poroid, yellowish grey (4B2), not changing on drying; pores daedaloid, lamellate to irregular, lamellae up to $3 \mathrm{~mm}$ thick and $4 \mathrm{~cm}$ long; context homogenous, light yellow (4A4), up to $10 \mathrm{~mm}$ in thickness; pore tubes light yellow (4A4), up to $2 \mathrm{~cm}$ in depth; margins acute, brownish

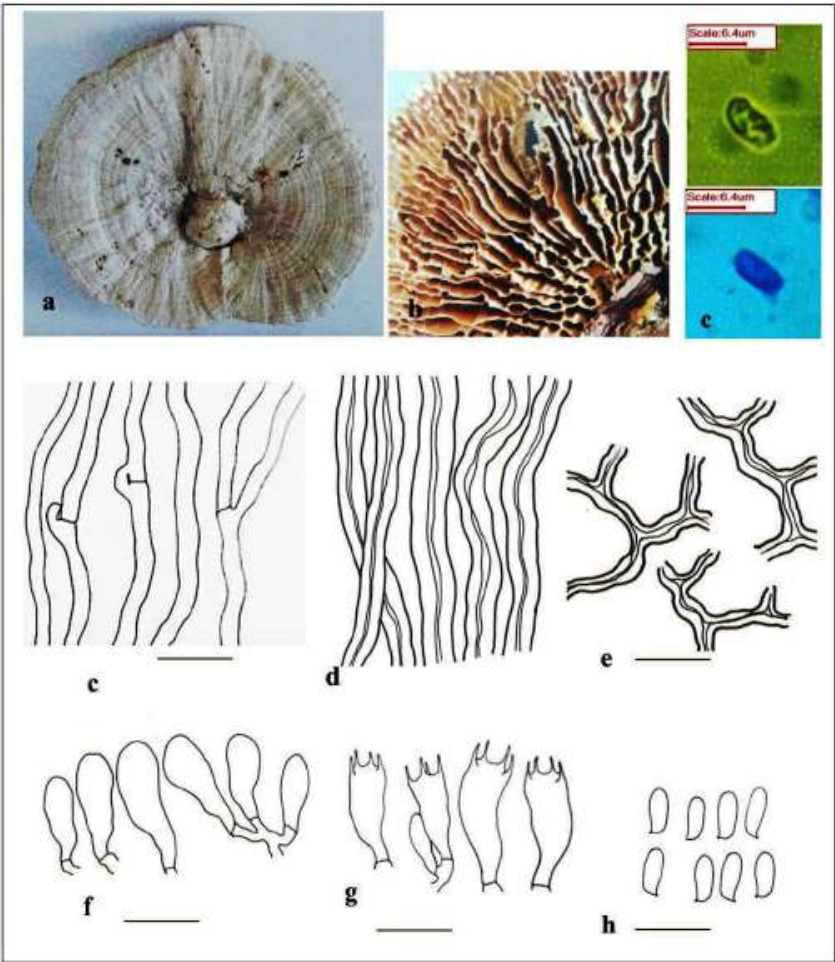

Fig.4. Daedalea quercina: a. Sporocarp (abhymenial surface), b. Hymenial surface, c. Basidiospores in water and cotton blue, d. Generative hyphae, e. Skeletal hyphae, f. Binding hyphae, g. Basidioles, h. Basidia, i. Basidiospores. Scale bar $\mathrm{d}-\mathrm{i}=10 \mu \mathrm{m}$

orange (5C5), up to $2 \mathrm{~mm}$ thick. Hyphal system trimitic. Generative hyphae thin-walled, hyaline, branched, clamped, up to $4 \mu \mathrm{m}$ in width. Skeletal hyphae dominating in context, thick-walled, aseptate, up to $6 \mu \mathrm{m}$ in width. Binding hyphae thick-walled, yellowish brown, with short branches, aseptate, up to $4 \mu \mathrm{m}$ in width. Basidia clavate, 4 - sterigmate, $14.9-18.4$ $\times 3.9$ - $4.6 \mu \mathrm{m}$. Basidiospores cylindrical, (5-) $5.5-6.8(-7) \times$ (2.4-) $2.6-3.1(-3.5) \mu \mathrm{m}, \mathrm{Q}=2.1$, thin-walled, smooth, $\mathrm{CN}$, IK:

Specimen examined: India, Tamil Nadu, Chennai, Guindy, in association with dead wood $13^{\circ} 00^{\prime} 06^{\prime \prime} \mathrm{N} 80^{\circ} 14^{\prime} 25^{\prime \prime} \mathrm{E}$, MLCASB346, 13.10.2017, Lakleiphi Tallanao; in association with dead wood, $13^{\circ} 00^{\prime} 35^{\prime \prime} \mathrm{N} 80^{\circ} 14^{\prime} 15^{\prime \prime} \mathrm{E}$, MLCASB332, MLCASB333, 31.10.2015, A. Arockia Mahimai Jayaseelan.

Comments: Daedalea quercina has comparatively larger basidiocarps with somewhat paler and velutinate pilear surface, irregulary daedaleoid hymenophore and homogenous, brown context. The previous Indian reports are from Maharashtra (Ranadive et al., 2011), Himachal Pradesh, Uttarakhand (Sharma, 2012) and Gujarat (Nagadesi et al., 2014).

5. Earliella scabrosa (Pers.) Gilb. \& Ryvarden, Mycotaxon 22 (2): 364 (1985).

Fig. 5

Basidiocarp annual, resupinate to effused-reflexed to pileate, broadly attached, tough and coriaceous when fresh, not changing much on drying; pileus up to $150 \times 110 \times 30 \mathrm{~mm}$; abhymenial surface glabrous, narrowly zonate, with 


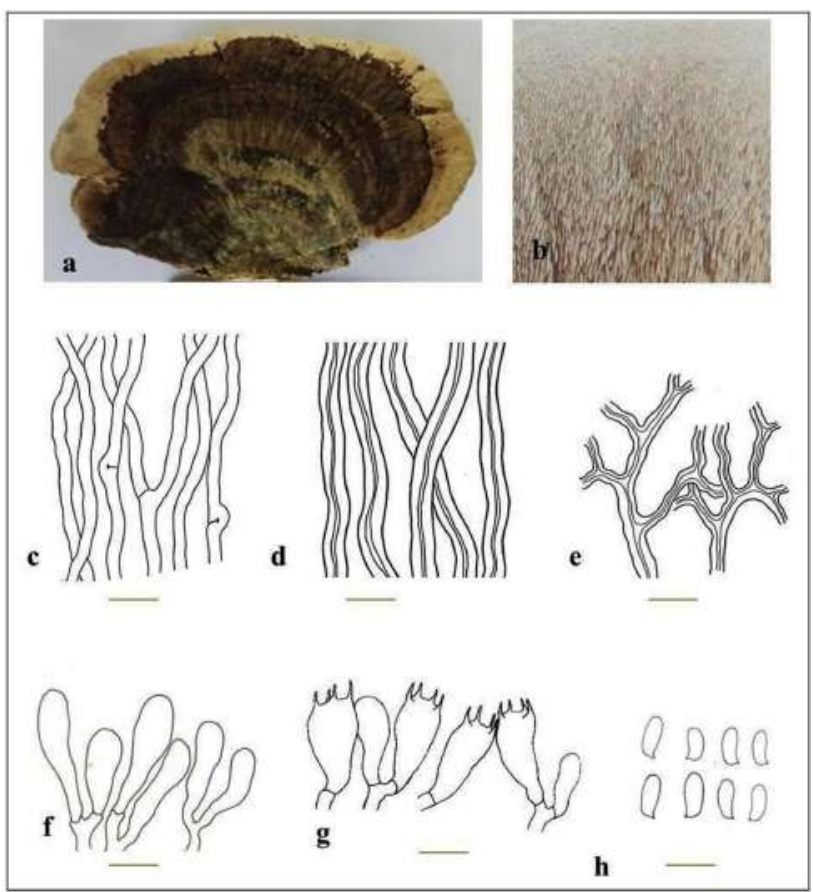

Fig. 5 Earliella scabrosa: a. Sporocarp (abhymenial surface), b. Hymenial surface, c. Generative hyphae, d. Skeletal hyphae, e. Binding hyphae, f. Basidioles, g. Basidia, h. Basidiospores. Scale bar $\mathrm{c}-\mathrm{h}=10 \mu \mathrm{m}$.

alternating bands of brown (7C4), pale brown (6A3), brown white (6A2) and greyish brown (5B4), with distinct reddish cuticle that is often slightly wrinkled on drying; hymenial surface poroid, pale white (5A3) when fresh, changing to deep brown (6A2) to light brown (6D2) on drying; pores angular to rarely somewhat hydnoid especially on sloping parts of the pileus, 3-4 per mm, individual pore elongated up to $5 \mathrm{~mm}$ in length; context homogenous, creamish white (5A2), up to $4 \mathrm{~mm}$ in thickness, with distinct dark lines under the red cuticle, tissue darkening in $\mathrm{KOH}$; pore tubes concolorous with the context, up to $6 \mathrm{~mm}$ in depth; margins acute, light brownish (6D2), up to $1 \mathrm{~mm}$ in thickness. Hyphal system trimitic. Generative hyphae thin-walled, branched, clamped, up to $3 \mu \mathrm{m}$ in width. Skeletal hyphae dominating, thick-walled, hyaline, aseptate, up to $5.5 \mu \mathrm{m}$ in width. Binding hyphae thick-walled, much branched, aseptate, up to $4 \mu \mathrm{m}$ in width. Basidia clavate, tetrasterigmate, $13.9-24.5 \times$ 4.2 - $6.6 \mu \mathrm{m}$. Basidiospores cylindrical, (7.1-) 7.9 - $9.5(-10) \times$ (3-) 3.2-3.5(-4) $\mu \mathrm{m}, \mathrm{Q}=2.4$, thin- walled, smooth, hyaline, $\mathrm{CN}^{-}, \mathrm{IK}^{-}$.

Specimen examined: India, Tamil Nadu, Chennai, Guindy, in association with dead wood, $\left(13^{\circ} 00^{\prime} 04^{\prime \prime} \mathrm{N}, 80^{\circ} 14^{\prime} 25^{\prime \prime} \mathrm{E}\right)$, MLCASB222,31.10.2015, G. Sugantha; in association with dead wood, $\left(13^{\circ} 00^{\prime} 05^{\prime \prime} \mathrm{N}, 80^{\circ} 14^{\prime} 25^{\prime \prime} \mathrm{E}\right)$, MLCASB343, 13.10.2017, Lakleiphi Tallanao; in association with dead wood, $\left(13^{\circ} 00^{\prime} 03^{\prime \prime} \mathrm{N}, 80^{\circ} 14^{\prime} 26^{\prime \prime E}\right)$, MLCASB355, 21.11.2017, A. Arockia Mahimai Jayaseelan; Adyar, in

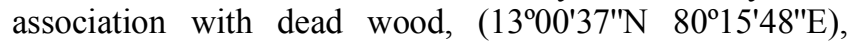
MLCASB304, 31.10.2015, Kezhocuyi Kezo.

Comments: The present specimens of Earliella scabrosa are consistent with the earlier reports except for the minor variations in the dimensions of basidiocarp and basidiospores. In India, it has been reported from West Bengal (Bakshi, 1971; Sharma and Ghosh, 1989; Roy and De, 1996), Uttarakhand (Dhanda, 1977; Roy and De, 1996; Sharma, 2000 and 2012), Assam (Roy and De, 1996), Kerala (Roy and De, 1996; Leelavathy and Ganesh, 2000), Natarajan and Kolandavelu (1998), Himachal Pradesh (Sharma, 2000 and 2012; Kaur, 2013; Kaur et al., 2017) and Punjab (Kaur, 2017). Natarajan and Kolandavelu (1998) reported this species as Trametes scabrosa from Thirunelveli.

6. Flavodon flavus (Klotzsch) Ryvarden, Norwegian Journal of Botany 20 (1): 3 (1973).

Fig. 6

Basidiocarp annual, resupinate to pileate, firmly attached, dimidiate; pileus up to $70 \times 50 \times 10 \mathrm{~mm}$; abhymenial surface tomentose, concentrically zonate with alternating zones of brown (6E8) and yellow (2A6), with age may become finely hispid; hymenial surface hydnoid with irregular teeth which are up to $2 \mathrm{~mm}$ thick, poroid towards the margin and younger basidiomata, round to angular up to 3 per $\mathrm{mm}, 5 \mathrm{~mm}$ deep, yellow (2A6) when fresh, olive yellow (2C7) on drying; context distinctly duplex, lower part dense, upper part loose, yellowish brown to olive brown (4D6), turning to reddish brown in $\mathrm{KOH}$, up to $2 \mathrm{~mm}$ in thickness; margins yellow (2A6), up to $2 \mathrm{~mm}$ thick. Hyphal system dimitic. Generative hyphae thin- to slightly thick-walled, hyaline, simple septate, moderately branched, up to $4 \mu \mathrm{m}$ in width. Skeletal hyphae thick-walled, hyaline, rarely branched and encrusted, up to 7 $\mu \mathrm{m}$ in width, dominating in the context, sometime apical encrusted skeletal hyphae project into the hymenium.

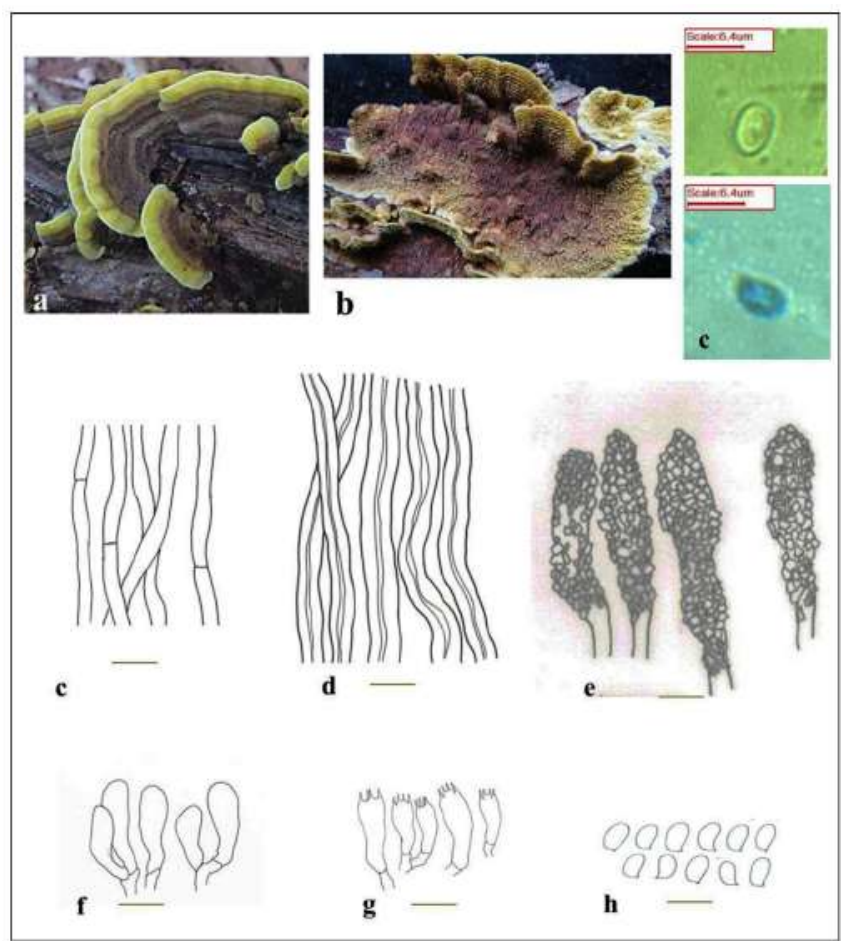

Fig.6 Flavodon flavus: a. Sporocarp (abhymenial surface), b. Hymenial surface, c. Basidiospores in water and cotton blue, d. Generative hyphae, e. Skeletal hyphae, f. Binding hyphae, g. Basidioles, h. Basidia, i. Basidiospores. Scale bar $\mathrm{d}-\mathrm{i}=10 \mu \mathrm{m}$. 
Cystidia thick-walled, abundant, apically encrusted, 25 - $45 \times$ 5 - $7 \mu \mathrm{m}$. Basidia clavate, 4-sterigmate, $14.8-18 \times 4.7-5.6$ $\mu \mathrm{m}$. Basidiospores ellipsoid, (5-) 5.5 - 6.5 (-7) $\times(3-) 3.5$ - 4 (4.5) $\mu \mathrm{m}, \mathrm{Q}=1.5$, hyaline, thin-walled, smooth,; $\mathrm{CN}^{-}, \mathrm{IK}^{-}$.

Specimen examined: India, Tamil Nadu, Chennai, Guindy, in association with dead wood, $\left(13^{\circ} 00^{\prime} 35^{\prime \prime} \mathrm{N}, 80^{\circ} 14^{\prime} 25^{\prime \prime} \mathrm{E}\right)$, MLCASB006, 10.09.2015, Kezhocuyi Kezo; in association with dead wood, $\left(13^{\circ} 00^{\prime} 03^{\prime \prime} \mathrm{E}, 80^{\circ} 14^{\prime} 26^{\prime \prime} \mathrm{N}\right)$, MLCASB230, 31.10.2017, Kezhocuyi Kezo.

Comments: The morpho-taxonomic studies of the present specimens are in conformity with the earlier reports except for the larger cystidial size and minor variations in basidiospore size. The earlier Indian account of $F$. flavus is from West Bengal (Banerjee, 1947; Roy and De, 1996), Chandigarh (Dhanda, 1977), Uttarakhand (Dhanda, 1977; Sharma, 2000), Bihar (Roy and De, 1996), Madhya Pradesh (Roy and De, 1996), Uttar Pradesh (Roy and De, 1996), Tamil Nadu (Natarajan and Kulandavelu, 1998), Kerala (Leelavathy and Ganesh, 2000), Maharashtra (Ranadive et al., 2011) and Himachal Pradesh (Sharma, 2012).

7. Hexagonia hirta (P. Beauv.) Fr., Epicrisis Systematis Mycologici:496(1838).

Fig.7

Basidiomata annual, pileate, sessile, solitary to imbricate, dimidiate to flabelliform, applanate, corky when fresh, leathery on drying; pileus up to $80 \times 50 \times 8 \mathrm{~mm}$ thick; abhymenial surface greyish brown (6E3) when fresh, turning to dark brown (7F4) on drying, densely covered with dark hairs up to $6 \mathrm{~mm}$ long, hairs disappearing or completely falling off with age leaving concentrically zonate surface;

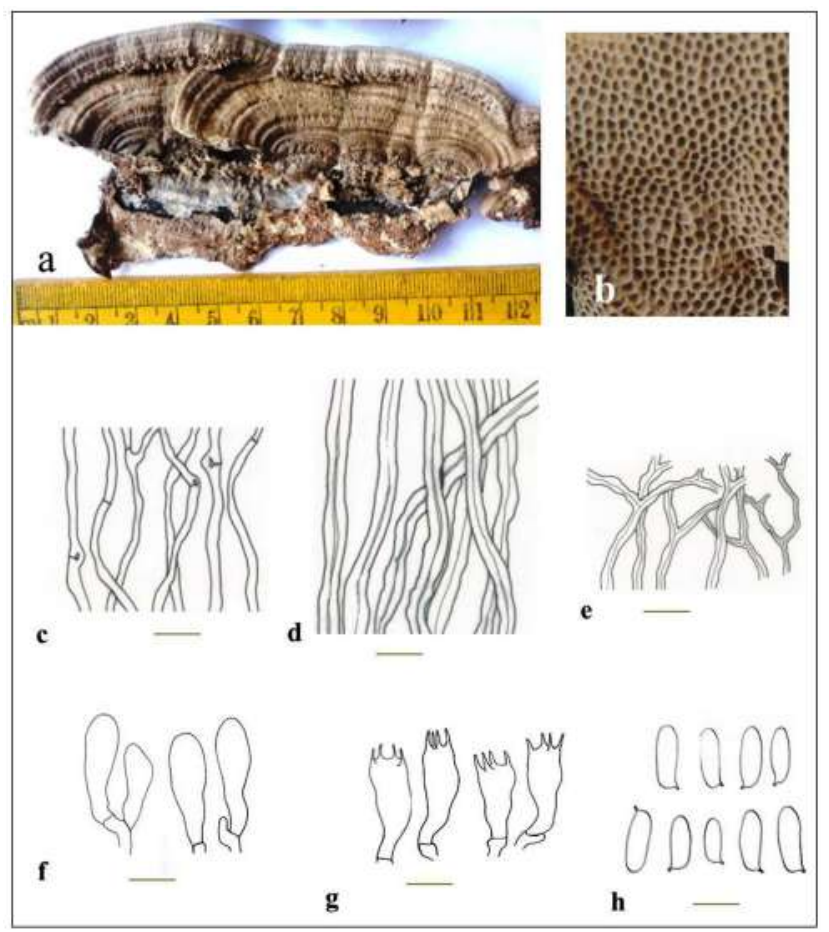

Fig. 7 Hexagonia hirta: a. Sporocarp (abhymenial surface), b. Hymenial surface, c. Generative hyphae, d. Skeletal hyphae, e. Binding hyphae, f. Basidioles, g. Basidia, h. Basidiospores. Scale bar $\mathrm{c}-\mathrm{h}=10 \mu \mathrm{m}$. hymenial surface poroid, brownish grey $(7 \mathrm{C} 2)$; pores angular to hexagonal, often radially elongated, 1-2 per mm; context homogenous, light brown (6D4), up to $2 \mathrm{~mm}$ in thickness, tissue turning dark brown in $\mathrm{KOH}$; pore tubes light brown (6D4), up to $3 \mathrm{~mm}$ in depth; margins acute, thin, greyish brown (6E3), up to $1 \mathrm{~mm}$ thick. Hyphal system trimitic. Generative hyphae thin-walled, hyaline, branched, clamped, up to $2.5 \mu \mathrm{m}$ in width. Skeletal hyphae abundant, thickwalled, yellow to light brown, unbranched, aseptate, up to 5 $\mu \mathrm{m}$ in width. Binding hyphae thick-walled, hyaline, much branched, aseptate, up to $2.5 \mu \mathrm{m}$ in width. Basidia clavate, 4sterigmate, $15-25 \times 5-9 \mu \mathrm{m}$. Basidiospore cylindrical, (10.5-) 11.2 - $15(-15.8) \times(4-) 4.6-5(-5.7) \mu \mathrm{m}, \mathrm{Q}=2.6$, hyaline, smooth, thin walled, $\mathrm{CN}^{-}, \mathrm{IK}^{-}$.

Specimen examined: India, Tamil Nadu, Chennai, Guindy, in association with dead wood, $13^{\circ} 00^{\prime} 05^{\prime \prime} \mathrm{N} 80^{\circ} 14^{\prime} 26^{\prime \prime} \mathrm{E}$, MLCASB348, 13.10.2017, Lakleiphi Tallanao.

Comments: The annual pileate, dimidiate to flabelliform applanate basidiocarp, densely strigose abhymenial surface with long, dark hairs and large hexagonal pores are the distinct characters of Hexagonia hirta. It has been report from Himalaya (Bakshi, 1971), Arunachal Pradesh (Sharma, 2000 and 2012), Tamil Nadu (Kandasamy et al., 2016) and Himachal Pradesh (Kaur, 2013; Kaur et al., 2017).

8. Hexagonia tenuis (Hook.) Fr., Epicrisis Systematis Mycologici: 498 (1838).

Fig.8

Basidiocarp annual, pileate, sessile, broadly attached, solitary, rarely in clusters, flabelliform to semicircular, flat when fresh, often bent outward on drying, flexible and leathery both when fresh and on drying; pileus $40 \times 30 \times 3$

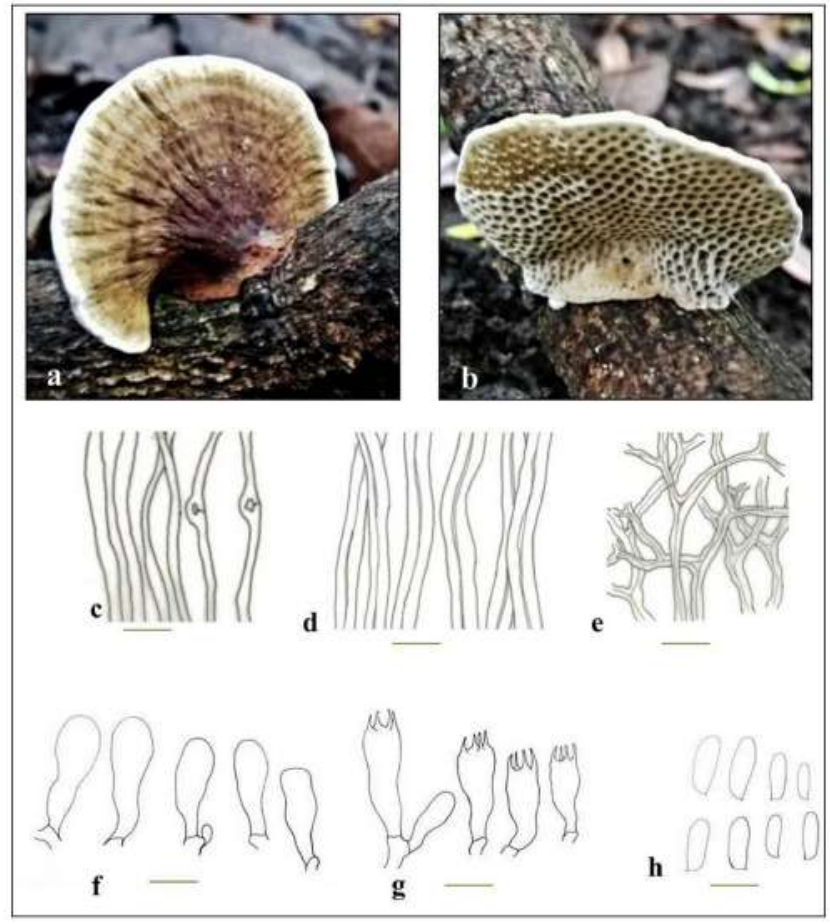

Fig. 8 Hexagonia tenuis: a. Sporocarp (abhymenial surface), b. Hymenial surface, c. Generative hyphae, d. Skeletal hyphae, e. Binding hyphae, f. Basidioles, g. Basidia, h. Basidiospores. Scale bar $\mathrm{c}-\mathrm{h}=10 \mu \mathrm{m}$. 
$\mathrm{mm}$; abhymenial surface glabrous, concentrically zonate, with alternating colours of light brown (5D5), yellowish brown (5E6), brown (5F8) and dark brown (6F6); hymenial surface poroid, milky white (5A1), often with greyish to ashybluish tint that turns greyish brown (5D3) on drying; pores angular to hexagonal, 1 - 2 per mm; context homogeneous, brown (5F8), up to $1 \mathrm{~mm}$ in thickness, tissue dark brown in $\mathrm{KOH}$; pore tubes greyish brown (5D3), up to $2 \mathrm{~mm}$ in depth; margins acute, slightly depressed, wavy, papery-thin, entire, sometimes lobed, up to $1 \mathrm{~mm}$ thick. Hyphal system trimitic. Generative hyphae, thin-walled, hyaline, branched, clamped, up to $3 \mu \mathrm{m}$ in width. Skeletal hyphae thick-walled, unbranched, yellow to pale brown, aseptate, up to $6 \mu \mathrm{m}$ in width. Binding hyphae hyaline thick-walled, coralloid to little branched aseptate, up to $4 \mu \mathrm{m}$ in width. Basidia somewhat collapsed, 4 - sterigmate, $17-28 \times 5-9 \mu \mathrm{m}$. Badiospores cylindrical, (8-) $9-13(-14) \times(2-) 3-5(-5.5) \mu \mathrm{m}, \mathrm{Q}=1.52$, hyaline, thin-walled, $\mathrm{CN}^{-}$, $\mathrm{IK}^{-}$.

Specimen examined: India, Tamil Nadu, Chennai, Tambarum, in association with dead wood, $\left(12^{\circ} 55^{\prime} 12^{\prime \prime} \mathrm{N}\right.$, $\left.80^{\circ} 07^{\prime} 15^{\prime \prime E}\right)$, MLCASB352, 13.10.2015, Tenzing Sangmo; Guindy, in association with dead wood, $\left(13^{\circ} 00^{\prime} 35^{\prime \prime} \mathrm{E}\right.$, $\left.80^{\circ} 14^{\prime} 16^{\prime \prime} \mathrm{N}\right)$, MLCASB018, 12.09.2016, Kezhocuyi Kezo; in association with dead wood, $\left(13^{\circ} 00^{\prime} 03^{\prime \prime} \mathrm{E}, 80^{\circ} 14^{\prime} 26^{\prime \prime} \mathrm{N}\right)$, MLCASB009, 31.10.2017, Kezhocuyi Kezo.

Comments: Hexagonia tenuis is easily identified by their dimidiate to flabelliform to semicircular basidisocarps with zonate pilear surface and hexagonal pores. In India, it has been reported from Kerala (Leelavathy and Ganesh, 2000; Mohanan, 2011), Gujarat (Arya et al., 2008), Maharashtra (Rathod, 2011 as Scenidium tenue), Himachal Pradesh (Sharma, 2012; Kaur, 2013), Uttarakhand (Sharma, 2012) and West Bengal (De, 2018). It is also listed in fungal data base of Tamil Nadu but without any description and reference.

9. Laetiporus sulphureus (Bull.) Murrill, Mycologia 12(1): 11 (1920).

Fig. 9

Basidiocarp annual, pileate, sessile, solitary to imbricate, dimidiate to flabelliform, fleshy and succulent when fresh, becoming lighter on drying; pileus up to $50 \times 40 \times 8 \mathrm{~mm}$, thickening towards the attachment; abhymenial surface faintly concentrically zonate with alternating colours of light brown (6D5), light orange (5A4) to grey orange (5B5); hymenial surface poroid, pale orange (5A3), not changing much on drying; pores angular, 3-4 per mm; context homogenous, white (5A1), up to $2 \mathrm{~mm}$ in thickness; pore tubes pale orange (5A3), up to $4 \mathrm{~mm}$ in depth; margins acute, brownish yellow (5C8), not more than $1 \mathrm{~mm}$ thick. Hyphal system dimitic. Generative hyphae thin-walled, hyaline, branched, simple septate, up to $5 \mu \mathrm{m}$ in width. Binding hyphae thick-walled, hyaline, irregularly branched, aseptate, up to $7 \mu \mathrm{m}$ in width. Basidia clavate, 4-sterigmate, $14-20 \times 5$ $-7 \mu \mathrm{m}$. Basidiospores ellipsoid, (5-) 5.2 - 7.5 (-8) $\times(3.5-) 4-5$ $(-5.3) \mu \mathrm{m}, \mathrm{Q}=1.52$, hyaline, smooth, thin walled, $\mathrm{CN}^{-}, \mathrm{IK}^{-}$.

Specimen examined: India, Tamil Nadu, Chennai, Guindy, on Pongamia pinnata $\left(13^{\circ} 00^{\prime} 35^{\prime \prime} \mathrm{E}, 80^{\circ} 14^{\prime} 16^{\prime \prime N}\right)$, MLCASB354, 12.09.2016, Kezhocuyi Kezo.

Comments: Laetiporus sulphureus is a common polypore

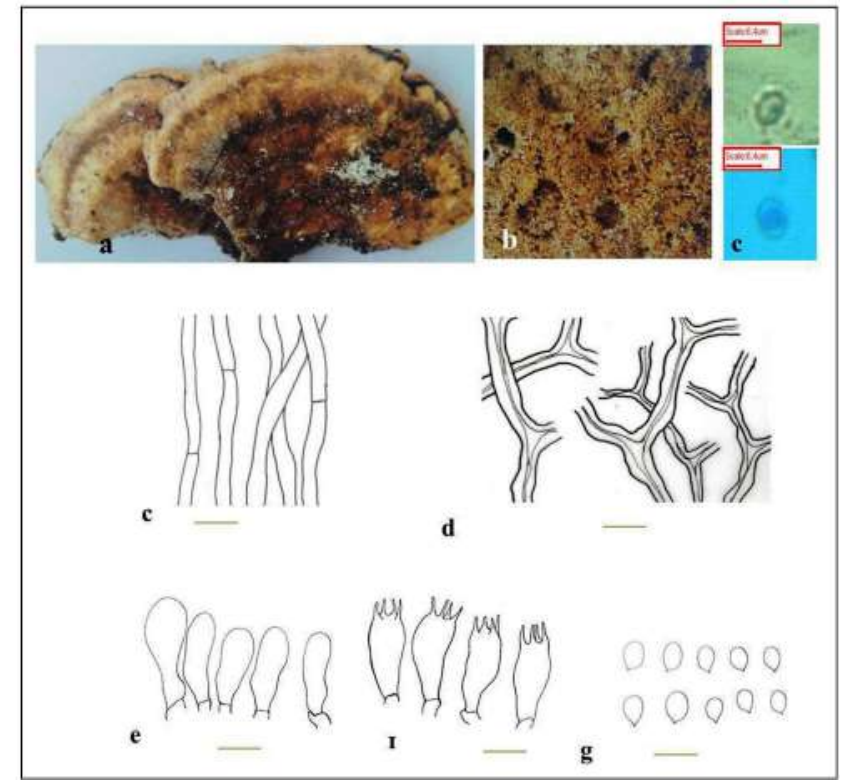

Fig. 9 Laetiporus sulphureus: a. Sporocarp (abhymenial surface), b. Hymenial surface, c. Basidiospores in water and cotton blue, d. Generative hyphae, e. Skeletal hyphae, f. Binding hyphae, g. Basidioles, h. Basidia, i. Basidiospores. Scale bar $\mathrm{d}-\mathrm{i}=10 \mu \mathrm{m}$.

which usually occurs in imbricate cluster. The bright yellow to orange basidiocarp with sappy or succulent consistency are the key identifying characters in the field. In India, it has been reported from Uttarakhand (Sharma, 2012), Gujarat (Korat et al., 2013; Rajput et al. 2015; Vasava et al., 2018), West Bengal (Tarafder et al., 2017), Tamil Nadu (Sivanandhan et al., 2018) and Madhya Pradesh (Verma et al., 2019).

10. Polyporus varius (Pers.) Fr., Systema Mycologicum 1: $352(1821)$.

Fig. 10

Basidiocarp annual, pileate, solitary, centrally to laterally stipitate, infundibuliform, depressed towards the stipe; pileus upto $60 \times 80 \times 4 \mathrm{~mm}$; abhymenial surface smooth, azonate, orange white (6A2) to brownish grey (6C2); hymenial surface poroid, pale orange $(5 \mathrm{~A} 3)$ when fresh, turning to greyish orange (5B4) on drying; pores round to angular, 6-9 per mm; context homogenous, white (6A1), up to $2 \mathrm{~mm}$ in thickness; pore tubes white (4A1), up to $1 \mathrm{~mm}$ in depth; margins acute, yellowish brown (6D8), $1-2 \mathrm{~mm}$ thick. Stipe lateral, with pale orange (6A3) apex and black base $(6 \mathrm{~F} 2)$, upto $15 \times 10$ $\mathrm{mm}$. Hyphal system dimitic. Generative hyphae thin-walled, hyaline, branched, clamped, up to $4 \mu \mathrm{m}$ in width. Binding hyphae thick-walled, much branched, aseptate, up to $5 \mu \mathrm{m}$ in width. Basidia clavate, 4-sterigmate, $14.4-24 \times 4.8$ - $7.2 \mu \mathrm{m}$. Basidiospores cylindrical, (8-) 8.5-9 (-10) × (2.5-) 3-4 (-4.5) $\mu \mathrm{m}, \mathrm{Q}=2.2$, hyaline, smooth, thin-walled, $\mathrm{CN}^{-}, \mathrm{IK}^{-}$.

Specimen examined: India, Tamil Nadu, Chennai, Guindy,

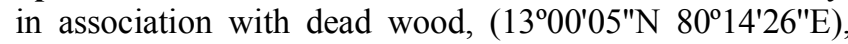
MLCASB342, 13.10.2017, Lakleiphi Tallanao.

Comments: Polyporus varius is unique in having infundibuliform, stipiate basidiocarps with depression towards the stipe and smooth pilear surface. The present specimen differs from the earlier reports (Sharma, 2012) in 


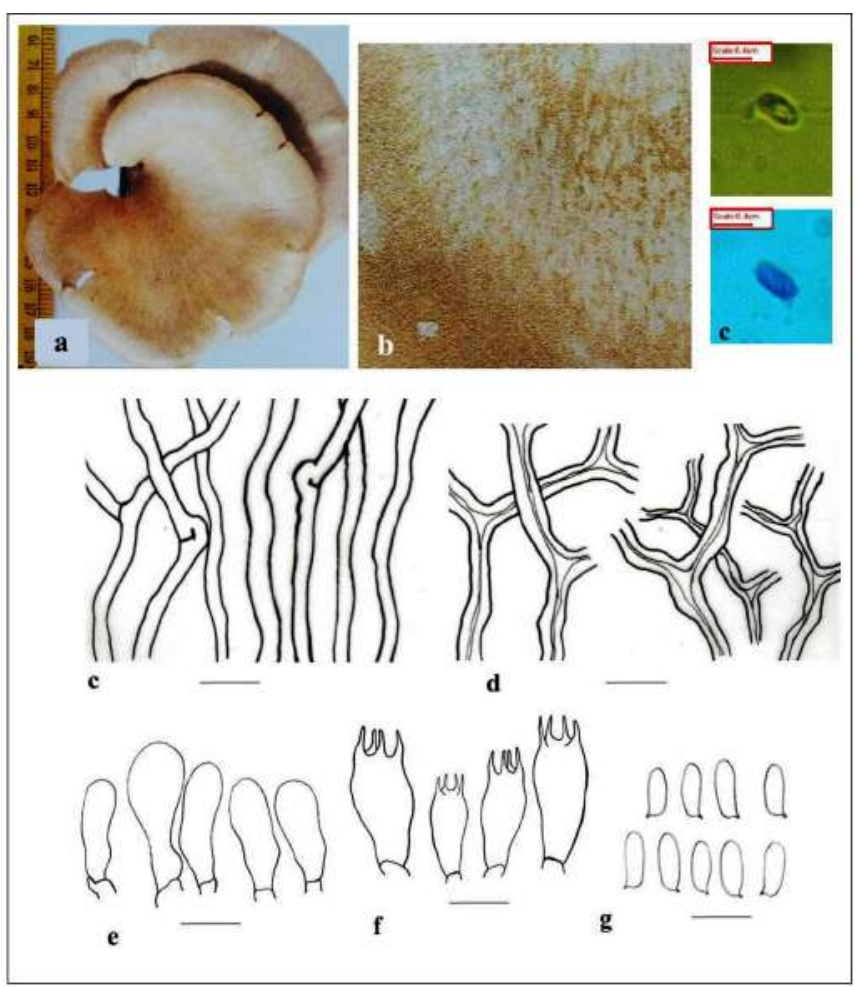

Fig. 10 Polyporus varius: a. Sporocarp (abhymenial surface), b. Hymenial surface, c. Basidiospores in water and cotton blue, d. Generative hyphae, e. Skeletal hyphae, f. Binding hyphae, g. Basidioles, h. Basidia, i. Basidiospores. Scale bar $\mathrm{d}-\mathrm{i}=10 \mu \mathrm{m}$.

lacking cytidioles. In India, it has been reported from Kerala (Mohanan, 2011; Adarsh et al., 2018), Himachal Pradesh and Meghalaya (Sharma, 2012) and Gujarat (Vasava et al., 2018).

11. Truncospora tephropora (Mont.) Zmitr., Folia Cryptogamica Petropolitana 6: 77, 2018.

Fig. 11

Basidiomata perennial, resupinate, effused, firmly attached, woody hard when fresh, brittle on drying, up to $170 \times 90 \times 10$ $\mathrm{mm}$; hymenial surface poroid, pale orange (5A3) when fresh, turning to greyish orange (5B3) on drying, often brownish orange (6C6) towards the margins; pores irregular, round to angular, 4-6 per mm; context homogenous, greyish brown (6D3), up to $2 \mathrm{~mm}$ in thickness, tissue darkening in $\mathrm{KOH}$; pore tubes stratified, brownish orange (6C5), each layer up to $4 \mathrm{~mm}$ in depth; margins brownish orange (6C6), less than 1 mm thick. Hyphal system trimitic. Generative hyphae thinwalled, hyaline, branched, clamped, up to $3 \mu \mathrm{m}$ in width, weakly dextrinoid. Skeletal hyphae dominating in context and tubes, thick-walled, pale brown, becoming olivaceous brown in $\mathrm{KOH}$, unbranched, aseptate, up to $5 \mu \mathrm{m}$ in width. Binding hyphae thin- to thick-walled, hyaline, much branched, aseptate, up to $3.8 \mu \mathrm{m}$ in width. Basidia clavate, 4sterigmate, $14-22.5 \times 4.5-6.3 \mu \mathrm{m}$. Basidiospores broadly ellipsoid, (4-) 4.5-5.8 (-6) × (3-) 3.2-4 (-4.5) $\mu \mathrm{m}, \mathrm{Q}=1.4$, hyaline, thin-walled, truncate and $\mathrm{CN}^{+}, \mathrm{IK}^{-}$.

Specimen examined: India, Tamil Nadu, Chennai, Guindy, in association with dead wood, $\left(13^{\circ} 00^{\prime} 33^{\prime \prime} \mathrm{E}, 80^{\circ} 14^{\prime} 16^{\prime \prime} \mathrm{N}\right)$, MLCASB026, 12.09.2016, Kezhocuyi Kezo.

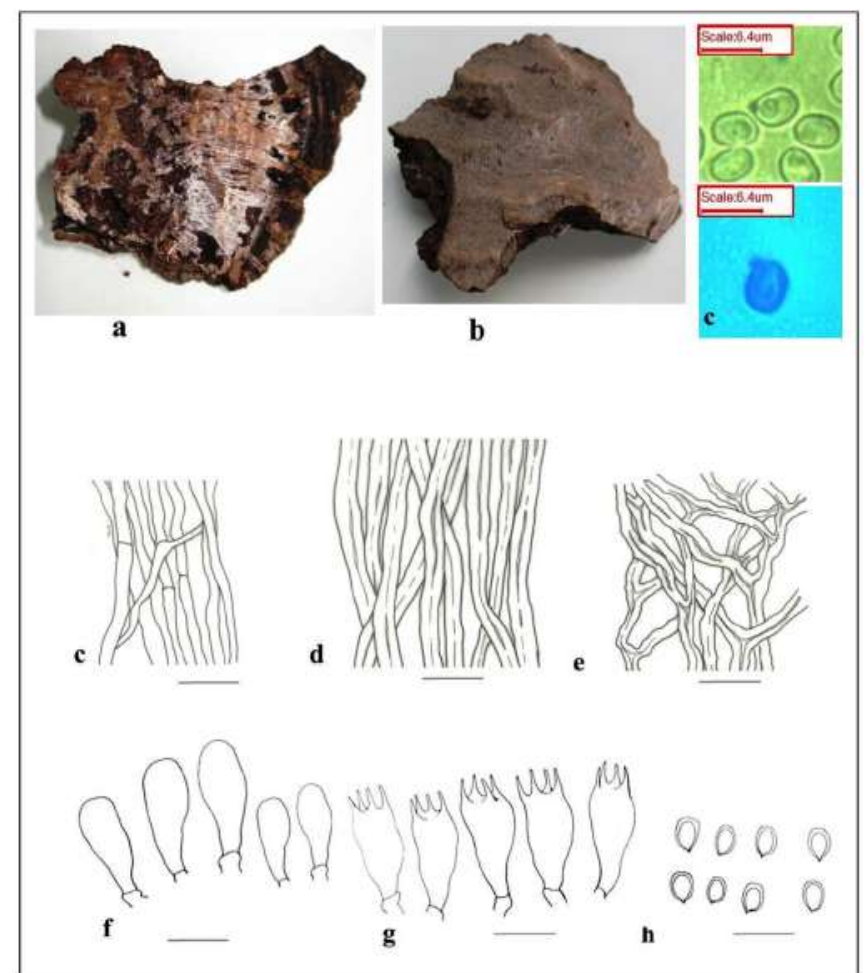

Fig. 11 Truncospora tephropora: a. Sporocarp (abhymenial surface), b. Hymenial surface, c. Basidiospores in water and cotton blue, d. Generative hyphae, e. Skeletal hyphae, f. Binding hyphae, g. Basidioles, h. Basidia, i. Basidiospores. Scale bar $\mathrm{d}-\mathrm{i}=10 \mu \mathrm{m}$.

Comments: It is characterized by resupinate basidiomata, trimitic hyphal system and hyaline, thin-walled, broadly ellipsoid, truncate basidiospores. In India, Natarajan and Kolandavelu (1998) reported it as L. tephroporus from Thirunelveli district of Tamil Nadu. Leelavathy and Ganesh (2000) and Kaur (2013) reported this species as Loweporus tephroporus from Kerala and Himachal Pradesh respectively.

\section{CONCLUSION}

In this paper eleven polypore species, namely Coriolopsis aspera, C. caperata, C. polyzona, Daedalea quercina, Earliella scabrosa, Flavodon flavus, Hexagonia hirta, $H$. tenuis, Laetiporus sulphureus, Polyporus varius and Truncospora tephropora are described for the first time from Chennai.

\section{ACKNOWLEDGEMENT}

The authors are thankful to Prof. N. Mathivanan, Director, CAS in Botany, University of Madras, Chennai for the encouragement and providing laboratory facilities.

\section{REFERENCES}

Adarsh, C.K., Vidyasagran, K. and Ganesh, P.N. 2018. A checklist of polypores of Kerala state, India. Studies in Fungi 3 (1): 202-226.

Arya, A., Albert, S. and Nagadesi, P.K. 2008. New and interesting records of basidiomycetous fungi from Ratanmahal wildlife sanctuary, Gujarat, India. $J$. Mycol.Pl. Pathol.38(2):221-226. 
Bakshi, B.K. 1971. Indian Polyporaceae (on trees and timber). Indian Council of Agricultural Research, New Delhi, India. 246 pp.

Banerjee, S.N. 1947. Fungus flora of Calcutta and Suburbs I. Bull. Bot. Soc. Bengal 1:37-54.

Binder, M. et al. 2005. The phylogenetic distribution of resupinate forms across the major clades of mushroom-forming fungi (Homobasidiomycetes). Syst. Biodivers. 3 (2):113-157.

Binder, M. et al. 2013. Phylogenetic and phylogenomic overview of the Polyporales. Mycologia 105: 13501373.

Bose, S.R. 1937. Polyporaceae of Lokra Hills, Assam. Annales Mycologici 35: 119-137.

Christensen, M. et al., 2005. Wood-inhabiting fungi as indicators of nature value in European beech forests. Monitoring and Indicators of Forest Biodiversity in Europe-From Ideas to Operationality, $229 \mathrm{pp}$.

De, A.B. 2018. Record of a new host of the wood-rotting fungus Hexagonia tenuis. Plant Pathology \& Quarantine 8(1): 58-62.

Dhanda, R.S. 1977. Studies on Polyporaceae of North Western Himalayas. Ph.D. Panjab University, Chandigarh. 500 pp.

Gäumann, E. 1926.Vergleichende Morphologie der Pilze Fischer, Jena. 503.

Gilbertson, R.L. and Ryvarden, L. 1986. North American Polypores, vol. 1, Fungiflora, Oslo.

MycoBank http://www.mycobank.org

Justo, A. et al. 2017. A revised family-level classification of the Polyporales (Basidiomycota). Fungal biol. 121: 798-824.

Kandasamy, S. et al. 2016. High Level Secretion of Laccase $(\mathrm{LccH})$ from a Newly Isolated White- Rot Basidiomycete, Hexagonia hirta MSF2. Front. Microbiol. 7: 707. doi: 10.3389/fmicb.2016.00707.

Kaur, H. 2013. Systematics of pileate poroid Agaricomycetes of Himachal Pradesh. Ph. D. thesis. Punjabi University, Patiala, India.

Kaur, G. 2017. Taxonomic studies on poroid and resupinate non-poroid Agaricomycetous fungi of Punjab and adjoining areas. Ph. D. thesis. Punjabi University, Patiala $341 \mathrm{pp}$.

Kaur, R., Kaur, H., Singh, A.P., Kaur, G. and Dhingra, G.S. 2017. Some noteworthy additions to family Polyporaceae from Himachal Pradesh. Kavaka 49: 10-14.

Kezo K. et al. 2019. Taxonomic characterization and diversity of wood inhabiting Polypores from Chennai. Kavaka 52: 122-129.

Kirk, P. M. Sutton, B.C. and Pegler, D.N. 2008. Dictionary of the Fungi (10 ${ }^{\text {th }}$ ed.), Wallingford Oxon, UK, 771 pp.

Kornerup, A. and Wanscher, J. H. 1981. Taschenlexikon der Farben (3. Aufl.). Muster-Schmidt Verlag, Göttingen.

Korat, C., Chopada, G. and John, P. 2013. Studies on biodiversity of fleshy fungi in Navsari (South Gujarat), India. International Journal of Biodiversity and Conservation 5 (8): 508-514.

Leelavathy, K. M. and Ganesh, P.N. 2000. Polyporaceae of Kerala. Daya Publishing House, Delhi. 165 pp.

Malarvizhi, K. 2014. Phylogenetic relationships of Ganoderma species based on Mitochondrial and nuclear DNA sequences from Tamil Nadu. Proceedings of the 8th International Conference on Mushroom Biology and Mushroom Products: 113121.

Mohanan, C. 2011. Macrofungi of Kerala. Kerala Forest Research Institute, Peechi, Kerala, India, 670 pp.

Natarajan, K. and Kolandavelu, K. 1998. Resupinate Aphyllophorales of Tamil Nadu. CAS in Botany, University of Madras, Chennai. $133 \mathrm{pp}$.

Nagadesi, P.K., Bhavani, J. and Arya, A. 2014. New records of Lignicolous fungi from Krishna District, Andhra Pradesh, India. International letters of Natural Science 12 (1): 55-69.

Núñez, M. and Ryvarden, L. 2001. East Asian Polypores. Synopsis Fungorum 2(14): 170-182.

Priyamvada, H. et al. 2017. Terrestrial macrofungal diversity from the tropical dry evergreen biome of Southern India and its potential role in Aerobiology. PLoS ONE 12 (1): e0169333.

Rajput, K.S. et al. 2015. Preliminary checklist of fungi of Gujarat State, India. Current Research in Environmental \& Applied Mycology 5 (4): 285-306.

Ranadive, K.R. et al. 2011. Checklist of Aphyllophorales from the Western Ghats of Maharashtra State, India. Mycosphere 2: 91-114.

Rathod, M.M. 2011. Taxonomic studies on the daedaloid and hexagonoid polypores form the forest of western Maharashtra. Recent Research in Science and Technology 3 (5): 50-56.

Roy, A. and De, A. 1996. Polyporaceae of India. International Book Distributor, Dehradun 248 001, India, pp. $207-$ 210.

Selvam, K. et al. 2012. Identification and Screening of wood rot fungi from Western Ghats area of South India, Int. J. Chemtech Res. 4:379-388.

Sharma, J.R. 2000. Genera of Indian Polypores. Botanical Survey of India, Ministry of Environment and Forests, Calcutta. 188 pp.

Sharma, J.R. 2012. Aphyllophorales of Himalayas. Botanical Survey of India, Ministry of Environment and 
Forests, Calcutta. 590 pp.

Sharma, J.R. and Ghosh, P.K. 1989. Polypores that decay tree of Indian Botanic Garden. Bulletin of Botanical Survey of India 31: 95-102.

Sivanandhan, S. et al. 2018. Larvicidal, ovicidal, and histopathological effects of the sulphur polypore mushroom, Laetiporus sulphureus (Agaricomycetes), collected from Tamil Nadu, India against mosquitoes. International Journal of Medicinal Mushrooms 20 (12): 1197-1207.

Sundaramani, S. and Madurajan, D. 1925. Some Polyporaceae of Madras Presidency. Madras Agricultural Department Year Book: 69-75 pp.
Tarafder, E. et al. 2017. Contributions to the macromycetes of West Bengal, India. 13-17. Research Journal of Pharmacyand Technology 10 (4): 1123-1130.

Vasava, A.M. et al. 2018. Distribution and diversity of Polyporaceae in Western India: An overview and addition to mycoflora of the Gujarat state. Plant Science Today 5(1): 32-38.

Verma, R. et al. 2019. Diversity of macro-fungi in Central India-XXII: Diversity of Laetiporus sulphureus in TFRI campus. Van Sangyan 6(4): 1-7. 